\title{
IAMJ
}

INTERNATIONAL

AYURVEDIC

MEDICAL JOURNAL

미요 (1)

Research Article

ISSN: 23205091

Impact Factor: 5.344

\section{EXPERIMENTAL STUDIES ON VARIOUS LOHA PREPARATIONS W.S.R TO "MRITANI LOHANI RASI BHAVANTI"}

\author{
Amit Mishra ${ }^{1}$, Neha Prajapati ${ }^{2}$ Mukesh Chaudhari ${ }^{3}$, Amit Sharma ${ }^{4}$ \\ ${ }^{1}$ P.G. Scholar, Department of Rasashastra and Bhaishajya Kalpana, NIA Jaipur, Rajasthan, India \\ ${ }^{2}$ P.G. Scholar, Department of Dravyaguna, NIA Jaipur, Rajasthan, India \\ ${ }^{3} \mathrm{Ph} . \mathrm{D}$ Scholar, Department of Rasashastra and Bhaishajya Kalpana, NIA Jaipur, Rajasthan, India \\ ${ }^{4} \mathrm{Ph} . \mathrm{D}$ Scholar, Department of Rasashastra and Bhaishajya Kalpana, NIA Jaipur, Rajasthan, India
}

Corresponding Author: dr.amitmishra8269@gmail.com

https://doi.org/10.46607/iamj1508102020

(Published online: October 2020)

Open Access

(C) International Ayurvedic Medical Journal, India 2020

Article Received: 19/09/2020 - Peer Reviewed: 29/09/2020 - Accepted for Publication: 04/10/2020

(A) Check for updates

\begin{abstract}
Ayurvedic system of medicine is the only one out of all traditional system of medicine where importance of metals for curing ailments was probably first recognized. Iron is the fourth common element and second most common metal in the earth crust and is a biologically essential component of every living organism. Despite the low requirement of iron in human body iron overload is rare and iron deficiency is common in certain parts of the world and in certain age groups6. Iron containing drugs used as hematinics are known to induce some adverse drug reactions -- gastrointestinal symptoms (nausea, vomiting, epigastric pain, colic pain, flatulence, constipation, black feces, and diarrhea. Iron containing compounds like Loha Bhasma, Kasis Bhasma and Mandura Bahsma are practiced since long and are indicated in a wide spectrum of diseases and can be a better alternative from Rasa shastra. Pharmacokinetics is proposed to study the absorption, the distribution, the bio transformations and the elimination of drugs in man and animals. A primary aim of pharmacokinetics analyses is to determine bioavailability. Evaluation of Pharmaco kinetics of Loha bhasma, Kasis bhasma and Mandura bhasma were carried out. Serum iron was estimated using AAS. Parameters like Cmax, Tmax etc. were calculated
\end{abstract}

Keywords: Loha Bhasma, Kasis Bhasma, Mandura Bahsma, Cmax, Tmax. 


\section{INTRODUCTION}

Traditional medicines are used in the treatment of various chronic disorders and for the improvement of wellbeing of individuals. Loha Bhasmas have been prescribed by Ayurvedic physicians since long with rare mentions of toxicity. It is observed that herbomineral complexes are more stable and more interactive compared to plain herbs as these result in faster therapeutic action and have a longer shelf life ${ }^{1}$. In traditional methods of processing employed in Ayurveda, the metals are repeatedly subjected to Shodana (purification with naturally available ingredients), bhavana (trituration with herbal juice) and Bhasmikarana (calcination) to obtain the final product. These processes reduce the final product to nanometer size, which is believed to enhance its bioavailability and reduce its toxicity ${ }^{2}$. Pharmacokinetics which deals with the absorption, distribution, metabolism and excretion of the biomarkers or the new drug entity is the one of the regulatory requirements for an investigational new drug approval. Bioactive guided pharmacokinetic approach method is needed for Ayurvedic system of medicine to determine the pharmacokinetics of relevant markers in the formulation having number of markers ${ }^{3}$. The mentioned Verse is in the text like Rasendra Mangal, Rasarnava, Ras Ratna Samuchchaya, Ras Ratnakar, the verse signifies that the absorption and assimilation of different types of Bhasma of minerals / metals / sub metals \& Sindoora Kalpana for internal administration in human body. In Ayurvedic formulations the concept of drug action and absorption is designed on the basis of the Panchamahabhuta theory, Agni, Rasa, Guna, Virya, Vipaka etc. of the drug. Pharmacokinetics studies supports the studies of preclinical toxicology in animals (toxicokinetics) because the drug levels in plasma or tissues are often more predictive than the dose to extrapolate the toxicity data to man. To go for the bio availability of the Ayurvedic formulations especially Herbo minerals is a daunting task but they provide strong evidence base to the safety and efficacy of herbo-mineral formulations. The present pharmacokinetic study was undertaken with a view to identify a few pharmacokinetic parameters for the iron containing preparations like Loha, Kasis and Mandura bhasma.

\section{Aim and Objectives}

- To carry out pharmacokinetic study of iron containing formulations like Loha Bhasma, Kasis bhasma and Mandura bhasma in rats.

- To determine the time dependent concentrations of administered drugs (Loha, Kasis and Mandura bhasma) in the collected serum of each animal

- To determine the Cmax, Tmax, etc. of the administered drugs.

To compare the pharmacokinetic parameters of the test drugs with that of the standard drug Ferrous sulphate.

\section{Materials and Methods}

\section{- $\quad$ Test Drugs}

1. Loha bhasma, 2. Kasis bhasma, 3. Mandura bhasma The samples were prepared in the Dept. of Rasashastra and Bhaishajya Kalpana, N.I.A. Jaipur.

- Standard drug, Ferrous sulphate

\section{- Selection of Animals and Animal Care}

The experiment was carried out in Biomedical and Industrial Lab, Jaipur. Ethical clearance was obtained from Institutional Animal Ethics Committee, before conducting the experiment (IAECAPPROVAL NO: ibir/iaec/2015/II/7). The study was conducted on mature Sprague-Dawly rats, weighing $150-200 \mathrm{~g}$. Animals were acclimatized for a period of seven days in laboratory conditions prior to the experiments. Rats were housed in poly propylene cages (six rats per cage), at an ambient temperature of $25 \pm 2{ }^{\circ} \mathrm{C}$ with $12 \mathrm{~h}$ light: 12 $\mathrm{h}$ dark cycle in the animal house of Biomedical and Industrial Lab. The animals were provided with standard pellet diet and water ad libitum. The Principles of Laboratory Animal Care were followed throughout the duration of the experiment.

- Instruments used: Weighing scale, needle, syringe, mono pan balance, rubber catheter, mortar \& pestle, surgical instruments, cannula, sterilizer, pipette, glass slides, Beaker $(40 \mathrm{ml}, 100 \mathrm{ml}, 250 \mathrm{ml})$, Measuring cylinder $(100 \mathrm{ml}, 10 \mathrm{ml}, 50 \mathrm{ml})$, volumetric flask (100 ml), Sterile Blood Collection Vile etc.

- Dose Calculation: The dose was calculated by extrapolating the human dose to animal based on the 
body surface area ratio by referring to the table of Paget and Barnes (1969).

- Dose conversion: Animal dose $=$ Human Dose $\mathrm{x}$ $0.018 \times 5 / \mathrm{kg}$ body weight, Considering the human dose of Loha Bhasma, Kasis Bhasma and Mandura Bhasma as $250 \mathrm{mg}$, the dose to be administered in rats were calculated as $22.5 \mathrm{mg} / \mathrm{kg}$ body weight.

- Mode of administration: Animals in each group were dosed as per the study design presented in table. Animals were kept fasting for 24 hours prior administration of drugs All the animals were weighed before dose administration and volume required for each animal was calculated according to weight. Dose formulations were prepared on the day of dosing. Sample of test drugs Loha Bhasma, Kasis Bhasma and Mandura Bhasma and the standard drug ferrous sulphate were taken $2 \mathrm{~g}$ each in porcelain mortar and $2 \% \mathrm{CMC}$ was added, the formed mixture was further ground for 5 minutes and the volume was made up with distilled water, so as to contain the required dose in solution.. The prepared suspension was administered orally with the help of feeding needle attached to a disposable $1 \mathrm{ml}$ syringe. Care was taken that no air bubble was passed at the time of dosing.

Table 1: Showing Grouping of animals

\begin{tabular}{|l|l|l|}
\hline Group & No of rats & Intervention \\
\hline Group A: & 6 & $2 \%$ CMC Solution $5 \mathrm{ml} / \mathrm{kg}$ ) per oral. \\
\hline Group B: & 6 & Kasis Bhasma $22.5 \mathrm{mg} / \mathrm{kg}$ per oral, single dose \\
\hline Group C: & 6 & Loha Bhasma $22.5 \mathrm{mg} / \mathrm{kg}$ per oral, single dose \\
\hline Group D: & 6 & Mandura Bhasma $22.5 \mathrm{mg} / \mathrm{kg}$ per oral, single dose \\
\hline Group E: & 6 & Ferrous Sulfate $22.5 \mathrm{mg} / \mathrm{kg}$ per oral, single dose \\
\hline
\end{tabular}

- Procedure of blood withdrawal: Rats were anesthetized by using ketamine and xylane mixture (90:10, IP, Dose volume: $2 \mathrm{ml} / \mathrm{kg})^{4}$. A $2 \mathrm{~cm}$ ventral cervical skin incision was made right of the midline. Underlying salivary and lymphatics were separated by means of blunt dissection to visualize the right common jugular vein. Jugular vein was then isolated from surrounding tissues and a pair of thread was passed below the blood vessel. Tunnel was made with the help of trocar to exteriorize the cannula towards neck. The exteriorized part was made secure in place with 3-0 lifeline sterile thread. Skin incision was closed, and the exteriorized cannula was filled with stock solution (100 IU/Ml of heparinized saline.)

- Blood Sampling: Blood samples were collected post dosage $0 \mathrm{~min}, 30 \mathrm{~min}, 60 \mathrm{~min}, 90 \mathrm{~min}, 120$ $\mathrm{min}, 180 \mathrm{~min}$ and $240 \mathrm{~min}$ in microfuge tubes containing K2EDTA $(20 \mu \mathrm{L} / \mathrm{mL}$ of blood, $200 \mathrm{mM})$ as anticoagulant. In jugular vein catheterized rats, after each sampling, equal volume of heparinized saline $(10 \mathrm{IU} / \mathrm{mL})$ was injected. Plasma was harvested from blood by centrifugation of samples at $2500 \mathrm{~g}$ for $10 \mathrm{~min}$ at $4^{\circ} \mathrm{C}$ and stored below $-60^{\circ} \mathrm{C}$ until bio analysis ${ }^{5}$.

- Statistical analysis: Exposure (Cmax) between different groups for oral dose administration were compared for statistical significance using a oneway Analysis of Variance (ANOVA) with Tukey's multiple comparisons set. A P value of less than 0.05 was considered significant. The statistical analysis was performed using Graph Pad instant software version 3 .

\section{Observations and Results}

After administration of vehicle to the control group A the serum the blood samples were collected at $0, .5,1$, 1.5, 2, 3 and 4 hours respectively. However, the serum iron concentration was at non detectable level in all rats during the whole period. 
Table 2: Showing serum iron concentration of Group B rats at various time interval post dosing of Kasis Bhasma.

\begin{tabular}{|c|c|c|c|c|c|c|c|c|}
\hline \multirow[t]{2}{*}{ Time Point (hours) } & \multicolumn{8}{|c|}{ Serum iron concentration $\mathrm{mg} / \mathrm{l}$ of group B rats } \\
\hline & 1 & 2 & 3 & 4 & 5 & 6 & Mean & SD \\
\hline 0 & ND & ND & ND & ND & ND & ND & - & - \\
\hline 0.5 & 0.85 & 0.86 & 0.87 & 0.84 & 0.83 & 0.85 & 0.85 & 0.0141 \\
\hline 1 & 0.72 & 0.72 & 0.75 & 0.71 & 0.73 & 0.69 & 0.72 & 0.0200 \\
\hline 1.5 & 0.68 & 0.71 & 0.69 & 0.65 & 0.69 & 0.67 & 0.616 & 0.6816 \\
\hline 2 & 0.46 & 0.50 & 0.42 & 0.43 & 0.49 & 0.48 & 0.463 & 0.0326 \\
\hline 3 & ND & ND & ND & ND & ND & ND & - & - \\
\hline 4 & ND & ND & ND & ND & ND & ND & - & - \\
\hline
\end{tabular}

As mentioned in table no. 2 following administration of Kasis Bhasma serum iron concentration was non detectable assuming it to be zero at 0 hour followed by a mean plasma concentration of $.85 \mathrm{mg} / \mathrm{ml}$ at 5 hour. The concentration then decreased to .72 at 1 hour, 0.616 at
1.5 hours, .463 at 1.5 hours and finally was non detectable at 3 and 4 hours post dosing. Maximum concentration Cmax was found to be $.85 \mathrm{mg} / \mathrm{l}$ and Tmax. 5-hour post dosing as depicted in the graph 1 .

Table 3: Showing serum iron concentration of Group C rats at various time interval post dosing of Loha bhasma.

\begin{tabular}{|l|l|l|l|l|l|l|l|l|}
\hline \multirow{2}{*}{ Time Point (hours) } & \multicolumn{9}{|c|}{ Serum iron concentration $\mathbf{~ m g / l ~ o f ~ g r o u p ~ C ~ r a t s ~}$} \\
\cline { 2 - 10 } & $\mathbf{1}$ & $\mathbf{2}$ & $\mathbf{3}$ & $\mathbf{4}$ & $\mathbf{5}$ & $\mathbf{6}$ & Mean & SD \\
\hline $\mathbf{0}$ & ND & ND & ND & ND & ND & ND & - & - \\
\hline $\mathbf{0 . 5}$ & 1.28 & 1.22 & 1.34 & 1.25 & 1.31 & 1.27 & 1.278 & 0.042 \\
\hline $\mathbf{1}$ & 0.58 & 0.61 & 0.63 & 0.55 & 0.53 & 0.57 & 0.577 & 0.034 \\
\hline $\mathbf{1 . 5}$ & 0.45 & 0.43 & 0.41 & 0.49 & 0.47 & 0.46 & 0.452 & 0.026 \\
\hline $\mathbf{2}$ & 0.25 & 0.29 & 0.31 & 0.19 & 0.21 & 0.26 & 0.252 & 0.041 \\
\hline $\mathbf{3}$ & 0.12 & 0.15 & 0.13 & ND & ND & 0.11 & 0.124 & 0.016 \\
\hline $\mathbf{4}$ & ND & ND & ND & ND & ND & ND & - & - \\
\hline
\end{tabular}

Following administration of Loha Bhasma serum iron concentration was non detectable assuming it to be zero at 0 hour followed by a mean plasma concentration of $1.278 \mathrm{mg} / 1$ at .5 hour. The concentration then decreased to .577 at 1 hour,0.452at 1.5 hours, .252 at 1.5 hours,.124 at 3 hours and finally was non detectable at 4 hours post dosing. Maximum concentration Cmax was found to be $1.278 \mathrm{mg} / \mathrm{l}$ and Tmax. 5-hour post dosing as depicted in the graph 2 .

Table 4: Showing serum iron concentration of Group D rats at various time interval post dosing of Mandura Bhasma.

\begin{tabular}{|l|l|l|l|l|l|l|l|l|}
\hline \multirow{2}{*}{ Time Point (hours) } & \multicolumn{9}{|l|}{ Serum iron concentration $\mathrm{mg} / \mathrm{l}$ of group D rats } \\
\cline { 2 - 10 } & $\mathbf{1}$ & $\mathbf{2}$ & $\mathbf{3}$ & $\mathbf{4}$ & $\mathbf{5}$ & $\mathbf{6}$ & Mean & SD \\
\hline $\mathbf{0}$ & ND & ND & ND & ND & ND & ND & - & - \\
\hline $\mathbf{0 . 5}$ & 0.36 & 0.35 & 0.38 & 0.37 & 0.34 & 0.35 & 0.358 & 0.014 \\
\hline $\mathbf{1}$ & 0.43 & 0.40 & 0.46 & 0.49 & 0.37 & 0.44 & 0.431 & 0.042 \\
\hline $\mathbf{1 . 5}$ & 0.53 & 0.52 & 0.55 & 0.54 & 0.51 & 0.52 & 0.528 & 0.014 \\
\hline $\mathbf{2}$ & 0.47 & 0.46 & 0.49 & 0.48 & 0.45 & 0.46 & 0.468 & 0.014 \\
\hline $\mathbf{3}$ & 0.17 & 0.16 & 0.19 & 0.18 & 0.15 & 0.18 & 0.171 & 0.014 \\
\hline $\mathbf{4}$ & ND & ND & ND & ND & ND & ND & - & - \\
\hline
\end{tabular}


Following administration of Madura bhasma serum iron concentration was non detectable assuming it to be zero at 0 hour followed by a mean plasma concentration of $.358 \mathrm{mg} / \mathrm{ml}$ at .5 hour. At 1 hour it increased to .431 $\mathrm{mg} / \mathrm{l}$. The concentration then decreased to .528 at 1.5 hour, 0.468 at 2 hours, .171 at 3 hours and finally was non detectable at 4 hours post dosing. Maximum concentration Cmax was found to be $0.528 \mathrm{mg} / \mathrm{l}$ and Tmax 1.5 -hour post dosing as depicted in the graph 3.

Table 5: Showing serum iron concentration of Group E rats at various time interval post dosing of standard ferrous sulphate.

\begin{tabular}{|c|c|c|c|c|c|c|c|c|}
\hline \multirow[t]{2}{*}{ Time Point (hours) } & \multicolumn{8}{|c|}{ Serum iron concentration $\mathrm{mg} / \mathrm{l}$ of group $\mathrm{E}$ rats } \\
\hline & 1 & 2 & 3 & 4 & 5 & 6 & Mean & SD \\
\hline $\mathbf{0}$ & ND & ND & ND & ND & ND & ND & - & - \\
\hline 0.5 & 0.18 & 0.15 & 0.12 & 0.24 & 0.21 & 0.19 & 0.181 & 0.042 \\
\hline 1 & 0.99 & 0.96 & 0.94 & 1.04 & 1.03 & 1.02 & 0.996 & 0.040 \\
\hline 1.5 & 0.53 & 0.52 & 0.55 & 0.54 & 0.51 & 0.52 & 0.551 & 0.042 \\
\hline 2 & 0.50 & 0.47 & 0.44 & 0.56 & 0.53 & 0.51 & 0.501 & 0.042 \\
\hline 3 & ND & ND & ND & 0.11 & ND & ND & 0.11 & - \\
\hline 4 & ND & ND & ND & ND & ND & ND & - & - \\
\hline
\end{tabular}

Following administration of ferrous sulphate serum iron concentration was non detectable assuming it to be zero at 0 hour followed by a mean plasma concentration of $.181 \mathrm{mg} / 1$ at .5 hour and increased to .996 at 1 hour. The concentration then decreased to .551 at 1.5 hours, .501 at 2 hours. At 3 hours no serum iron was detected all the blood samples except one which showed a value of .11. Serum iron became non detectable at 4 hours post dosing. Maximum concentration Cmax was found to be $0.996 \mathrm{mg} / \mathrm{l}$ and Tmax 1-hour post dosing as depicted in the graph 4 .
Graph 1. Serum iron concentration-time profile of Kasis bhasma following oral administration

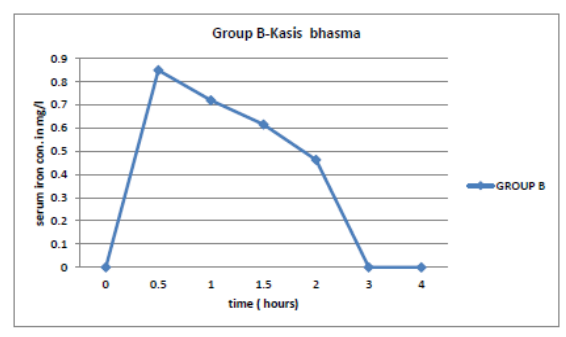

Graph 2. Serum iron concentration-time profile of Loha bhasma following oral administration

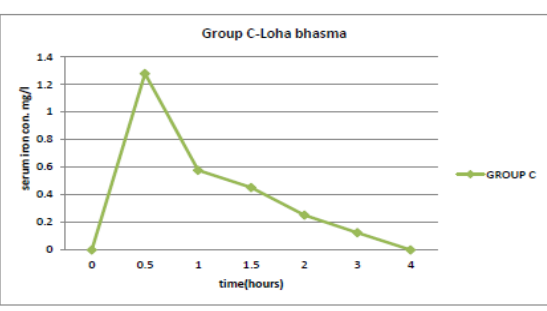

Graph 3. Serum iron concentrationtime profile of Mandura bhasma following oral administration

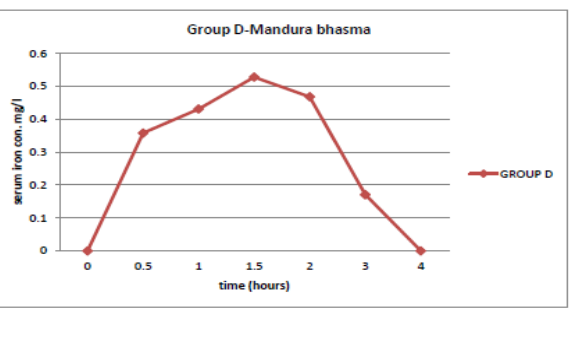


Graph 4: Serum iron concentration-time profile of ferrous sulphate following oral administration

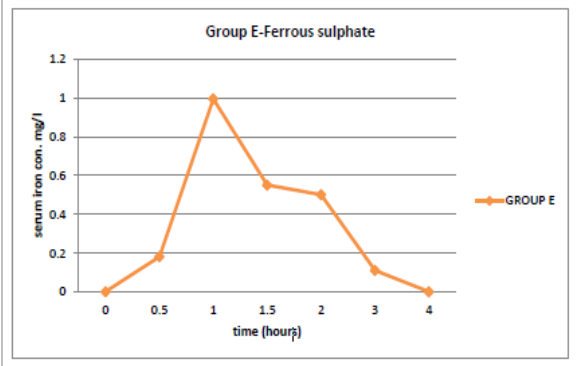

Graph 5. Serum iron concentrationtime profile of test drugs and standard following oral administration

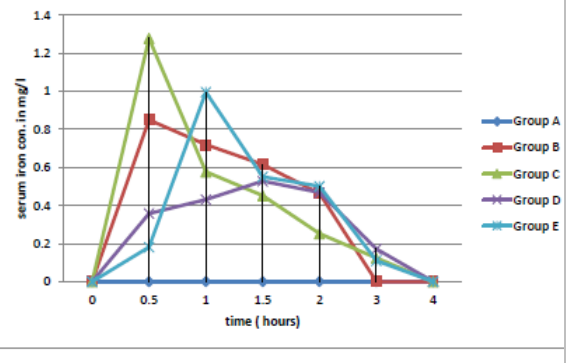

Graph 6: Showing Comparison of Cmax of various groups (group A excluded)

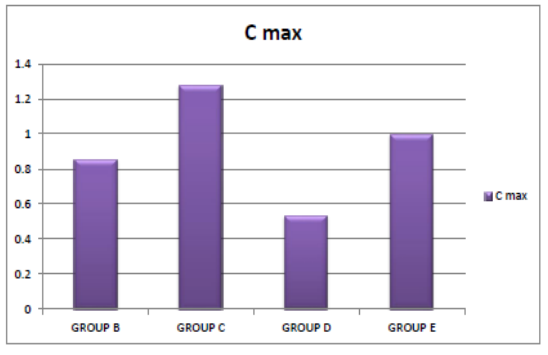

Table 6: showing Comparison of Cmax of various groups-One-way Analysis of Variance (ANOVA)

\begin{tabular}{|l|l|l|l|l|l|}
\hline S. No & Comparison & Mean Difference & q value & $\mathrm{P}$ value & Significance \\
\hline 1. & Group B Cmax Vs Group C Cmax & -0.4283 & 33.775 & $\mathrm{P}<0.001$ & $* * *$ \\
\hline 2. & Group B Cmax Vs Group D Cmax & 0.3217 & 25.364 & $\mathrm{P}<0.001$ & $* * *$ \\
\hline 3. & Group B Cmax Vs Group E Cmax & -0.1467 & 11.565 & $\mathrm{P}<0.001$ & $* * *$ \\
\hline 4. & Group C Cmax Vs Group D Cmax & 0.7500 & 59.139 & $\mathrm{P}<0.001$ & $* * *$ \\
\hline 5. & Group C Cmax Vs Group E Cmax & -0.2817 & 22.210 & $\mathrm{P}<0.001$ & $* * *$ \\
\hline 6. & Group D Cmax Vs Group E Cmax & -0.4683 & 36.929 & $\mathrm{P}<0.001$ & $* * *$ \\
\hline
\end{tabular}

\section{DISCUSSION}

At 0.5 -hour post administration of drug maximum concentration was reached by Loha bhasma which was $1.278 \mathrm{mg} / 1$ followed by Kasis bhasma which showed a serum concentration of $.85 \mathrm{mg}$ and Mandura bhasma $.358 \mathrm{mg} / 1$. The least serum iron concentration was for the standard drug ferrous sulphate at .05 hour. But at 1hour post administration ferrous sulphate showed the maximum concentration of $.996 \mathrm{mg} / 1$ followed by Kasis Bhasma and Loha Bhasma. Least serum iron concentration was for Mandura. At 1.5-hour post administration maximum concentration was seen in Loha administered group followed closely by standard group ferrous sulphate and Mandura. Least concentration was seen in iron administered group.

Cmax of group B, C, D and E were statistically analyzed using ANOVA. The comparison between the groups showed that the values were extremely significant. Thus, the study showed that the absorption and distribution of three Loha preparations differs according to the final Bhasma composition after interaction with various herbal complexes during its pharmaceutical processing.
The study showed that Cmax was higher for Loha Bhasma when compared to ferrous sulphate, Kasis and Mandura. Thus, the present work reveals that the absorption and plasma concentration of the three iron containing formulations are different even though the chemical composition is similar in the Bhasma. This can be attributed to the different processing of Bhasma and utilization of different herbs in their preparation which may have led to complex formation along with the major mineral part. The presence of different functional group was proved in analytical tests also. A higher concentration of Loha Bhasma can be attributed to the Triphala used in its preparation in a greater amount. Among the various ingredients Triphala which mainly consists of ascorbic acid (vitamin c), increases the bioavailability of iron by converting $\mathrm{Fe} 3+$ to $\mathrm{Fe} 2+$, while tannins and phenolics can reduce the iron by binding to it. In other words, this may also be taken as the various constituents of Triphala have antagonizing activity. The pharmacokinetics profiles of iron preparations thus provide useful information regarding the various aspect of drug activity of Bhasma preparations which can add to the evidence base of 
Ayurveda which further help in the global acceptance of Ayurvedic system of medicine.

\section{CONCLUSION}

Maximum concentration Cmax of Kasis bhasma was found to be $.85 \mathrm{mg} / 1$, for Loha bhasma $1.278 \mathrm{mg} / \mathrm{l}$, for Mandura bhasma $.528 \mathrm{mg} / 1$ and for standard 0.996 $\mathrm{mg} / 1$. Tmax of Kasis bhasma was 30 minutes post dosing, for Loha bhasma 30 minutes, for Mandura bhasma 90 minutes and for standard 60 minutes. The study showed that Cmax was higher for Loha bhasma when compared to ferrous sulphate and other Loha preparations Kasis and Mandura. Although Bhasmas are complex materials, experimental analysis using modern techniques will be most attractive for the standardization of Bhasma medicines. This would definitely help in building confidence in use of such products for medication by ensuring genuinely, safety, efficacy, and batch to batch uniformity.

\section{REFERENCES}

1. Singh VC. Nicholas Piramal India Ltd, Mumbai, Herbal (Ayurvedic) Drug Industry for Compliance to Quality parameters, Regional Training Course at India International Centre, New Delhi.

2. Sarkar PK, Chaudhary AK. Ayurvedic Bhasma: the most ancient application of nano medicine. J Sci Ind Res. 2010; 69: 901-905

3. Sudendra Honwad, A handbook of standardization of Ayurvedic Pharmaceutics. first edition 2012, Choukamba Orientalia; Varanasi: p.276

4. Vangala S, Mukkavilli R, Jadhav G, Kumar P, Praveen S, et al. (2015) Comparison of Pharmacokinetics of Dapsone in Male Sprague Dawley Rats Following Retro Orbital, Jugular Vein and Saphenous Vein Blood Sampling. SOJ Pharm Pharm Sci, 2(1), 1-10.

5. Subrahmanyam Vangala, Rao Mukkavilli, Gajanan Jadhav, Prasanna Kumar, Praveen S and Ajit Gadekar Comparison of Pharmacokinetics of Dapsone in Male Sprague Dawley Rats Following Retro Orbital, Jugular Vein and Saphenous Vein Blood Sampling, SOJ April 2015

\section{Source of Support: Nil Conflict of Interest: None Declared}

How to cite this URL: Amit Mishra et al: Experimental Studies On Various Loha Preparations W.S.R To "Mritani Lohani Rasi Bhavanti”. International Ayurvedic Medical Journal \{online\} 2020 \{cited October, 2020\} Available from: http://www.iamj.in/posts/images/upload/4662 4668.pdf 